\title{
Parasitylenchus sp. (Tylenchomorpha: Allantonematidae) parasitizing field populations of Harmonia axyridis (Coleoptera: Coccinellidae)
}

\author{
Susanne HARDing ${ }^{1}$, George O. POINAR JR ${ }^{2}$, Desislava V. Dimitrova ${ }^{1}$ and Tove STEENBERG ${ }^{3}$ \\ ${ }^{1}$ University of Copenhagen, Department of Agriculture and Ecology, Thorvaldsensvej 40, 1875 Frederiksberg C. (Copenhagen) \\ DK - Denmark; e-mail: suha@life.ku.dk \\ ${ }^{2}$ Oregon State University, Department of Zoology, 3029 Cordley Hall, Corvallis, Oregon 97331-2914; \\ e-mail: poinarg@science.oregonstate.edu \\ ${ }^{3}$ University of Aarhus, Department of Integrated Pest Management, Research Centre Flakkebjerg, Forsøgsvej 1, 4200 Slagelse, \\ DK - Denmark; e-mail: tove.steenberg@agrsci.dk
}

Key words. Coccinellidae, Harmonia axyridis, parasitic nematodes, Allantonematidae, Parasitylenchus sp., field parasitism, invasive species

\begin{abstract}
Adults of the invasive harlequin ladybird, Harmonia axyridis (Coleoptera: Coccinellidae), were found to be parasitized by nematodes (Tylenchomorpha: Allantonematidae) in Denmark. The nematodes were identified as Parasitylenchus sp. Major morphological characters of the nematodes did not differ significantly from Parasitylenchus coccinellinae Iperti \& van Waerebeke 1968, but minor deviations in egg dimension and tail length were measured. Parasitism was only recorded in early autumn, with prevalence ranging from 2 to $33 \%$. Adult and juvenile nematodes occurred together in the body cavity of both female and male $H$. axyridis.
\end{abstract}

\section{INTRODUCTION}

The harlequin ladybird, Harmonia axyridis Pallas (Coleoptera: Coccinellidae), is an invasive species native to central and eastern Asia. After release as a biological control agent, it has colonized most of the North American continent (Koch \& Galvan, 2008), and is currently increasing its area of invasion in Europe (Brown et al., 2008). Based on studies of the impact of natural enemies on $H$. axyridis in the colonized areas, it has been hypothesized that escape from natural enemies is a factor contributing to the high invasiveness of $H$. axyridis (Roy \& Cottrell, 2008; Cottrell \& Shapiro-Ilan, 2009).

During a survey of the field prevalence of different natural enemies in $H$. axyridis in Denmark, which has only recently been colonized (Steenberg \& Harding, 2010), we observed by dissection that some adult specimens of adult $H$. axyridis were parasitized by nematodes.

\section{MATERIAL AND METHODS}

Adult $H$. axyridis were collected from May to October 2009 on different plant species at four localities in Copenhagen. The coccinellids were incubated in groups of ca. 50 in ventilated plastic boxes and fed with aphids for 4 weeks to allow for emergence of parasitoids. They were then referred to gender and dissected under a stereomicroscope; specimens that died during the 4-week incubation period were dissected immediately. In total, $860 \mathrm{H}$. axyridis were sampled and dissected.

Nematodes from infected ladybird specimens were preserved in $70 \%$ ethanol, transferred to an ethanol-glycerol mixture and mounted in glycerol for microscopy.

\section{RESULTS}

Parasitization by nematodes was found in $26 \mathrm{H}$. axyridis in 2009. Both males and females were parasitized. All parasitized specimens were collected in September-October on Tilia sp. Parasitized ladybirds were found at three of the four localities. Parasitism rates in samples of 250, 100 and 120 specimens were
2, 7, and $11.6 \%$, respectively. Juvenile and adult nematodes occurred in the body cavity of the adult $H$. axyridis at all positive sampling events. Numbers varied, but up to several hundred or even thousand juveniles could be found in some specimens. Three supplementary samples of 30,41 , and $30 \mathrm{H}$. axyridis, respectively, were taken in October 2010 on shrubs underneath Acer sp. at three localities in Copenhagen and frozen immediately. Nematode prevalence in these samples was $10 \%, 10 \%$, and $33.3 \%$, respectively. Of these 17 parasitised coccinellids, 9 contained juvenile nematodes only, 1 contained numerous adults, and in $7 \mathrm{H}$. axyridis a mixture of adult and juveniles were present in the haemocoel. As in 2009, females as well as males contained nematodes.

The nematodes were identified as Parasitylenchus sp. The major morphological characters used for identification of the nematodes did not significantly differ from the description of Parasitylenchus coccinellinae by Iperti \& van Waerebeke (1968) (Fig. 1). The length of gravid females, the distance from vulva to apex expressed as \% of total body length, the length and width of free-living females all lie within the ranges described for P. coccinellinae. However, the egg dimension and the length of the tail of the nematodes found in $H$. axyridis exceed measures given by Iperti \& van Waerebeke (1968). We measured an average egg width of $28 \mu$ and a tail length of $64 \mu$ compared to $18-23 \mu$ and $30-41 \mu$ for eggs and tail, respectively in Propylea 14-punctata (Iperti \& van Waerebeke, 1968). These differences are not sufficient to warrant a new species at this time, however, more material and molecular analysis of nematodes are needed for a definitive species identification.

\section{DISCUSSION}

Parasitic nematodes infecting $H$. axyridis have so far only been reported from the Russian Far East within the species' native range (Filatova, 1970, cited in Kuznetsov, 1997). The nematodes infecting Coccinellidae in this region were, however, identified as Aphelencoides sp., a group of plant parasitic and 


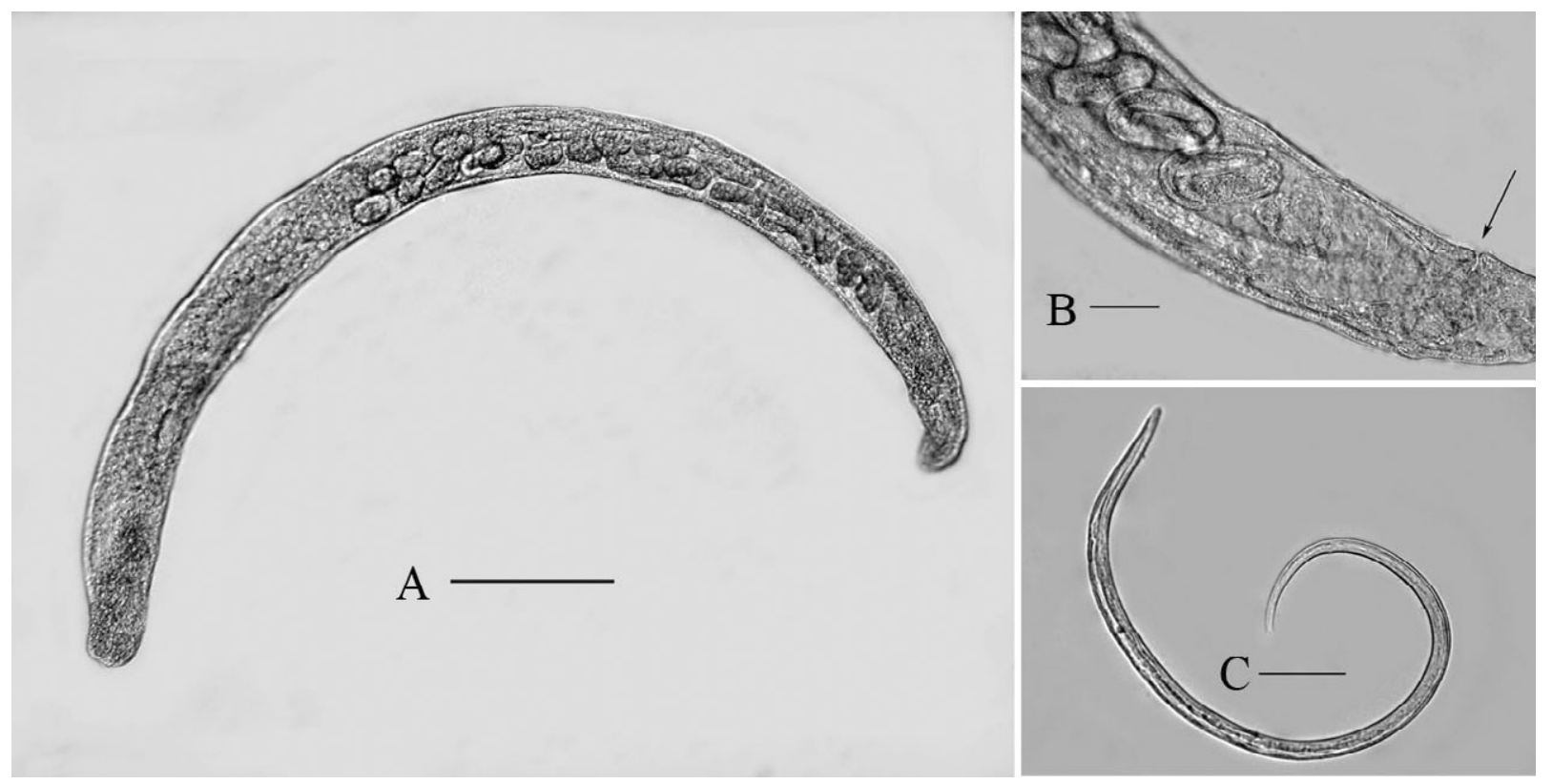

Fig. 1. A - mature female of Parasitylenchus sp. isolated from Harmonia axyridis. Scale bar 170 microns. B - developing eggs and vulva (arrow). Scale bar 37 microns. C - juvenile Parasitylenchus sp. from the body cavity of Harmonia axyridis. Scale bar 56 microns.

fungus-feeding nematodes, which are unlikely to reside in the body cavity of an insect; their identity is therefore uncertain.

Parasitylenchus coccinellinae was found as an endoparasite in adults of several multivoltine coccinellid species in SEFrance (Iperti, 1964), and has been recorded from India parasitizing the coccinellids Cheilomenes sexmaculata F. and Illeis indica Timb. (Narsi Reddy \& Narayan Rao, 1984). No other Parasitylenchus $\mathrm{sp}$. has been reported from coccinellids.

According to Iperti \& van Waerebeke (1968), P. coccinellinae completes almost all development within the host with mating occurring inside the coccinellid. The route of transmission is unknown, but was suggested to be via sexual contact. Yet, this hypothesis is not supported by the finding of infection only in early autumn. Transmission might also occur through the tracheae or through soft parts of the cuticle as suggested by Ceryngier \& Hodek (1996) and damp conditions late in the year may facilitate infection. It can not be rebutted that transmission has taken place during incubation in the boxes in 2009 , the $33 \%$ infection of specimens frozen immediately after sampling in 2010, however, reflects the true field prevalence. Also, the occurrence of nematodes in the coccinellids in autumn only is supportive of the hypothesis of transmission taking place in a damp environment.

Parasitism rates of up to $33 \%$ in a recently invaded area show, together with records of a high prevalence of pupal parasitisation by the phorid Phalacrotophora spp. (Steenberg \& Harding, 2010) and entomopathogenic fungi (Steenberg \& Harding, 2009) within the same sampling area, that natural enemies are adapting to $H$. axyridis in the introduced range. Further studies of the prevalence and transmission of the parasitic nematodes are required to evaluate the importance of this natural enemy to the population dynamics of $H$. axyridis.

Voucher nematode specimens from this study are deposited, together with host coccinellids, at Oregon State University in Corvallis and at the University of Copenhagen.

\section{REFERENCES}

Brown P.M.J., Adriaens T., Bathon H., Cuppen J., Goldarazena A., Hägg T., Kenis M., Klausnitzer B.E.M., Kovář I., Loomans A.J.M., Majerus M.E.N., Nedvěd O., Pedersen J.,
Rabitsch W., Roy H.E., Ternois V., Zakharov I.A. \& Roy D.B. 2008: Harmonia axyridis in Europe: spread and distribution of a non-native ladybird. BioControl 53: 5-21.

Ceryngier P. \& Hodek I. 1996: Enemies of Coccinellidae. In: Hodek I. \& Honěk A. (eds): Ecology of Coccinellidae. Kluwer Academic Publishers, Dordrecht, pp. 319-350.

Cottrell T.E. \& Shapiro-Ilan D.I. 2009: Naturally occurring pathogens and invasive arthropods. In Hajek A.E., Glare T.R. \& O'Callaghan M. (eds): Use of Microbes for Control and Eradication of Invasive Arthropods. Springer Science + Business Media B.V., pp. 19-32.

IPERTI G. 1964: Les parasites des coccinelles aphidiphages des les Alpes-Maritimes et les Basses-Alpes. Entomophaga 9: 153-180.

IPERTI G. \& VAN WAEREBEKE D. 1968: Description, biologie et importance d'une nouvelle espèce d'Allantonematidae (Nématoda), parasite des coccinelles aphidiphages: Parasitylenchus coccinellinae, n. sp. Entomophaga 13: 107-119.

KuzNetsov V.N. 1997: Lady Beetles of the Russian Far East. Memoir No. 1, Center for Systematic Entomology. The Sandhill Crane Press, Gainesville, 248 pp.

Koch R.L. \& Galvan T. L. 2008: Bad side of a good beetle: the North American experience with Harmonia axyridis. BioControl 53: 23-35.

Narsi Reddy Y. \& Narayan Rao P. 1984: First report of Parasitylenchus coccinellinae Iperti and Waerebeke (1968) from India in two new hosts Menochilus sexmaculatus (F) and Illeis indica Timb. Riv. Parassitol. 45: 133-137.

Roy H.E. \& Cottrell T.E. 2008: Forgotten natural enemies: Interactions between coccinellids and insect-parasitic fungi. Eur. J. Entomol. 105: 391-398

SteEnberg T. \& Harding S. 2009: Entomopathogenic fungi recorded from the harlequin ladybird, Harmonia axyridis. $J$. Invert. Pathol. 102: 88-89.

Steenberg T. \& Harding S. 2010: The harlequin ladybird (Harmonia axyridis Pallas) in Denmark: spread, phenology, colour forms and natural enemies in the early phase of establishment. IOBC/WPRS Bull. 58: 143-147.

Received June 28, 2010; revised and accepted December 22, 2010 